\title{
EVALUATION OF THE IMPLEMENTATION ONLINE VIRTUAL LEARNING IN ENGINEERING STUDENTS
}

\author{
Heri Suryaman $^{1}$, Suhartiningsih ${ }^{2}$, Yeni Anistyasari ${ }^{3}, \&$ Biyan Yesi Wilujeng $^{4}$ \\ ${ }^{1-4}$ Universitas Negeri Surabaya \\ herisuryaman@unesa.ac.id ${ }^{1}$, suhartiningsih@unesa.ac.id ${ }^{2}$, yenian@unesa.ac.id ${ }^{3}$, \\ biyanyesi@unesa.ac.id ${ }^{4}$
}

\begin{abstract}
Doing evaluation is one of important thing that has been done by the educators. This needs to be done as an effort to evaluate the implementation of online virtual learning for Engineering Students at Surabaya State University. The online virtual learning media used is the google meet application. The survey method was carried out by monitoring the implementation of direct learning in online virtual learning classes. Survey researched was employed to analyze the data, which directly used to monitor the students. The result of this study is that the implementation of online learning during the Covid-19 pandemic can be carried out well. Based on the Lesson Plan Semester,the results of the implementation of the Lesson Plan have been ready, carried out well, and the evaluation of the learning has been done well. The perceptions of lecturers and students shows that online virtual learning has met the minimum criteria of good and sufficient.
\end{abstract}

Keywords: Learning evaluation; Learning Implementation; Virtual Online

\begin{abstract}
Abstrak: Penelitian ini dilakukan dengan tujuan untuk mendeskripsikan hasil implementasi pembelajaran virtual online selama pandemi Covıd-19 terjadi. Hal ini perlu dilakukan sebagai upaya evaluasi terhadap implementasi pembelajaran virtual online pada mahasiswa Fakultas Teknik di Universitas Negeri Surabaya. Media pembelajaran virtual online yang digunakan sebagai obyek penelitian adalah aplikasi google meet. Metode survei dilakukan dengan cara monitoring terhadap implementasi pembelajaran secara langsung pada kelas pembelajaran virtual online. Hasil penelitian ini adalah ditemukan bahwa implementasi pembelajaran virtual online selama pandemic Covid-19 dapat terlaksana dengan baik dan terlaksana sesuai dengan rencana pembelajaran semester. Hasil implementasi pada keterlaksanaan pada rencana pembelajaran semester diperoleh persiapan pembelajaran telah siap, telah terlaksana dengan baik, dan evaluasi dari pembelajaran telah dilakukan dengan baik. Kualitas pembelajaran virtual ditinjau dari persepsi dosen dan mahasiswa menunjukkan bahwa pembelajaran virtual online telah memenuhi kriteria minimal baik dan cukup. Hambatan bagi mahasiswa adalah ketika saat perkuliahan secara virtual kondisi jaringan internet tidak stabil. Hambatan bagi dosen adalah sulitnya menilai keaktifan mahasiswa dalam belajar dan kejujuran mahasiswa dalam menyelesaikan tugas/ujian mengikuti pembelajaran virtual online untuk beberapa mata kuliah teori.
\end{abstract}

Kata kunci: Evaluasi pembelajaran; Implementasi Pembelajaran; Virtual Online

\section{INTRODUCTION}

When the COVID-19 pandemic occurs, teaching and learning process is done virtually through many applications which is existed. Such as G-Meet, Zoom, Google Classroom, etc. This is in accordance with a circular on health protocols from WHO, a circular from the Ministry of Education and Culture, and a circular by the Rector of Unesa on preventing the spread of covid19 in the campus environment. Both theoretical and practical learning in the laboratory must be replaced by online learning. Blended learning runs more effectively, student learning outcomes can increase when compared to traditional learning (Yigit et al., 2014). Learning evaluation can be used to determine the category of learning devices, feasibility, assessment, and minimum standards of graduation (Tompong \& Jailani, 2019). Online learning is learning that uses 
electronic circuits (LAN, WAN, or the internet) to convey learning content, interaction, or guidance (Jaya Kumar C. Koran, n.d.). There are 3 basic criteria that need to be understood in discussing online learning, namely online learning: (1) is a network that allows instant updating, storage / retrieval, distribution and various information systems or learning materials; (2) using computer equipment as a means of presentation by applying internet technology standards; (3) focuses on a broad view of learning including learning solutions that go beyond the traditional training paradigm (Hendriyana, 2011). Students need time to adapt when receiving the innovative learning strategies used (Savec \& Devetak, 2013). Learning modules using electronic media accompanied by discussions can provide increased understanding of concepts and problem solving (Wong et al., 2017). Applications can be used efficiently to complete student assignments (Alomari et al., 2020). Online learning using E-learning can increase student participation, motivation, and learning outcomes (Novo-corti et al., 2013). The characteristics of the learning model must be appropriate, sophisticated, have a strong theoretical basis, and be consistent (Limatahu \& Mubarok, 2020).

Learning evaluation is one of the important components and steps that must be taken by the teacher to determine the effectiveness of learning. The rsesults obtained can be used as feedback (feed-back) for teachers in improving and perfecting learning programs and activities. Evaluation as "a process for describing an evaluand and judging its merit and worth" (Lincoln, n.d.). "Evaluation is a process through which a value judgement or decision is made from a variety of observations and from the background and training of the evaluator" (Sax, 1989). The problems that will be examined in this study are how the implementation of virtual online learning during the Covid 19 pandemic. The specific purpose of this study is to determine the implementation of online virtual learning during the Covid 19 pandemic. The urgency of this research is due to the impact of the Covid 19 pandemic which causes physical distancing, wearing a mask and always washing hands. So that face-to-face lectures cannot be implemented. This is also in accordance with the Surabaya State University Chancellor's circular that lectures are conducted online. So this research is needed to determine the implementation of online learning in the engineering faculty in particular.

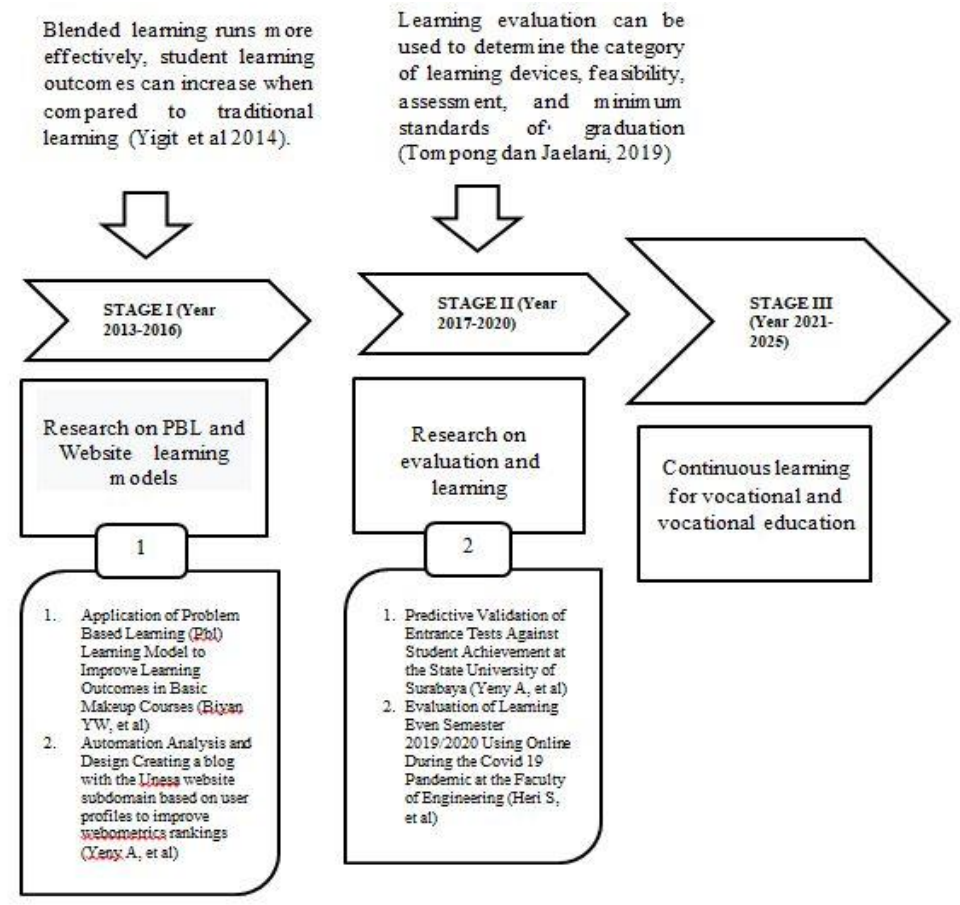

Figure 1. Research Roadmap 


\section{METHODS}

This study uses a survey research method which is carried out directly in the form of monitoring learning activities. The research subjects used were students and lecturers at the Faculty of Engineering, State University of Surabaya. The online virtual learning media used is Google meet application. The survey method in collecting research data during the implementation of online virtual learning includes four stages, namely: (1) Preparation to compile instruments for data collection on teaching preparation, the learning implementation process, and learning evaluation; (2) Data collection is carried out online and this activity is carried out in coordination in all study programs assisted by the Quality Assurance Unit (UPM) team in each department in the engineering faculty, this is done to determine which courses will be monitored and evaluated, monitored and evaluated is also carried out for lecturers and students during online virtual learning activities; (3) The instrument used in this study is presented in a google form which can be accessed by auditors online; and (4) Analysis of the data used using percentages. The results of the analysis can be used as a reference for improving the next semester's learning. The data collection design used questions, namely: (1) how was the implementation of online virtual learning during the Covid-19 pandemic; and (2) whether it has been implemented in accordance with the Lesson Plan Semester. The research instrument used in this study was a learning implementation observation sheet with the data sources are lecturers and students.

\section{RESULTS AND DISCUSSION}

Research on the evaluation of online virtual learning implementation for students includes two important objectives to be achieved, namely: (1) how is the implementation of online virtual learning during the Covid-19 pandemic; and (2) whether it has been implemented in accordance with Lesson Plan Semester. The results of implementation and compliance with the implementation of the Lesson Plan Semester are grouped into three stages. The first stage is preparation for learning, the second stage is the implementation of learning, and the third stage is the evaluation of learning. Data collection has been carried out online. This activity is carried out in coordination in all study programs assisted by the Quality Assurance Unit (UPM) team in each department in the engineering faculty. The instrument used for data retrieval is in the form of googleform which can be accessed by auditors online.

\section{First Stage - Learning Preparation}

The first stage of learning preparation includes 5 important indicators, namely: (1) Lesson Plan Semester (RPS) has been developed according to the curriculum and is relevant to needs; (2) the Lesson Plan Semester contains the achievement of graduate degrees; (3) the Lesson Plan Semester is planned to use a virtual online platform; (4) Lesson Plan Semester contains Fokus Group Discussion (FGD) activities, chat, and monitoring sheet activity; (5) Lesson Plan has been validated by UPM department. The results of data collection in the first stage are presented in Figure 2. 


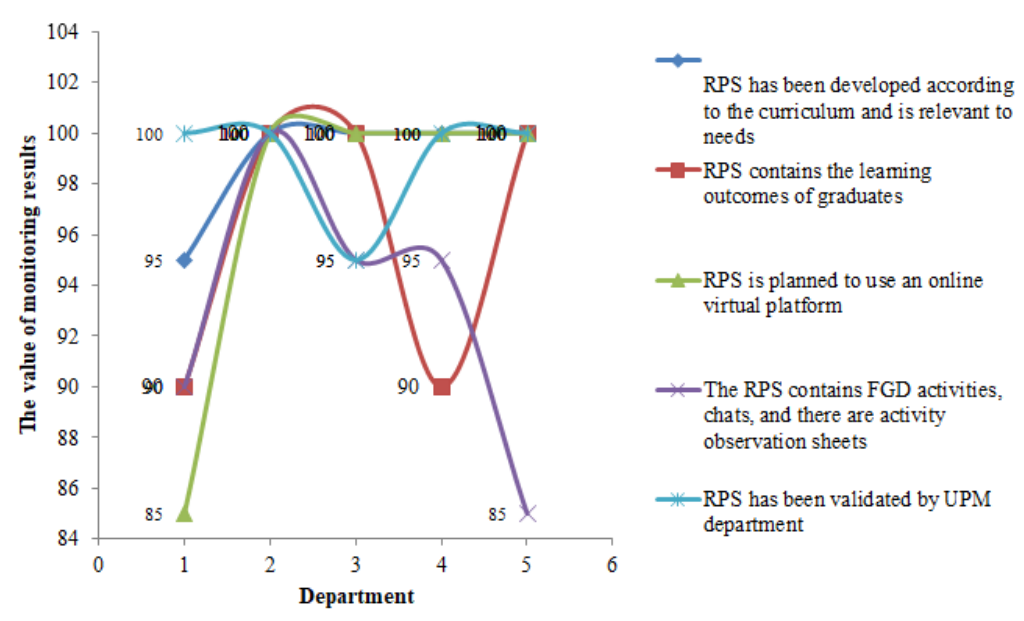

Figure 2. Results of the Learning Preparation Stage

The data in Figure 2 shows that the data mean value based on the five indicators is consecutively for Civil Engineering; Electrical Engineering; Mechanical Engineering; and Technical Information is $92.0 \% ; 100.0 \% ; 98.0 \%$; $97.0 \%$; and $97.0 \%$.

\section{Second Stage - Implementation of Learning}

The second stage of the implementation of learning includes 6 important indicators, namely: The lecturer provides directions for registration, use, and evaluation to students in using online virtual applications; (2) Lecturers upload / display teaching materials using online virtual applications; (3) Lecturers motivate students by using virtual online applications; (4) Lecturers provide active opportunities in learning using online virtual applications; (5) Lecturers give assignments using online virtual applications; and (6) Lecturers reflect using online virtual applications. The results of data collection in the second stage are presented in Figure 3.

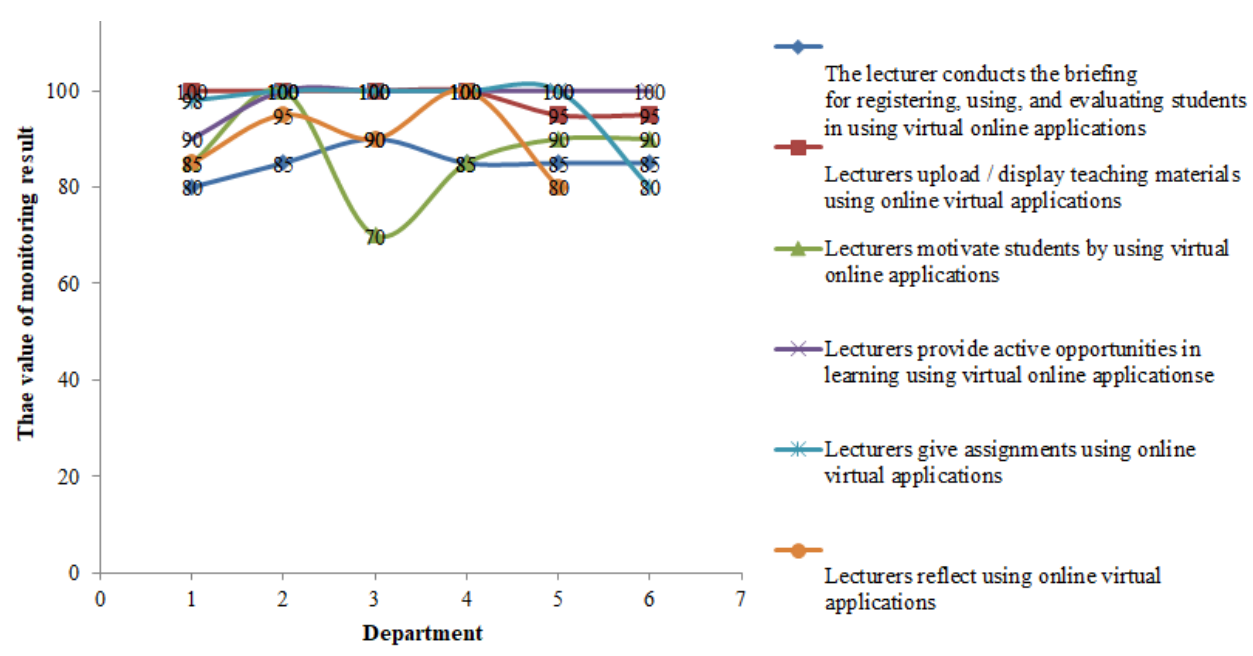

Figure 3. Results of the Learning Implementation Stage

The data in Figure 3 shows the average data value based on the six indicators for Civil Engineering; Electrical Engineering; Mechanical Engineering; and Technical Information is $85.0 \%$, respectively; $98.3 \%$; 86.7\%; 98.3; and 96.3\%.

\section{Third Stage - Learning Evaluation}


The third stage of learning evaluation includes 3 important indicators, namely: (1) the lecturer provides an assessment; (2) the lecturer returns the assignment; and (3) the lecturer gives midterm exam (UTS) and final exams (UAS). The results of data collection in the second stage are presented in Figure 4.

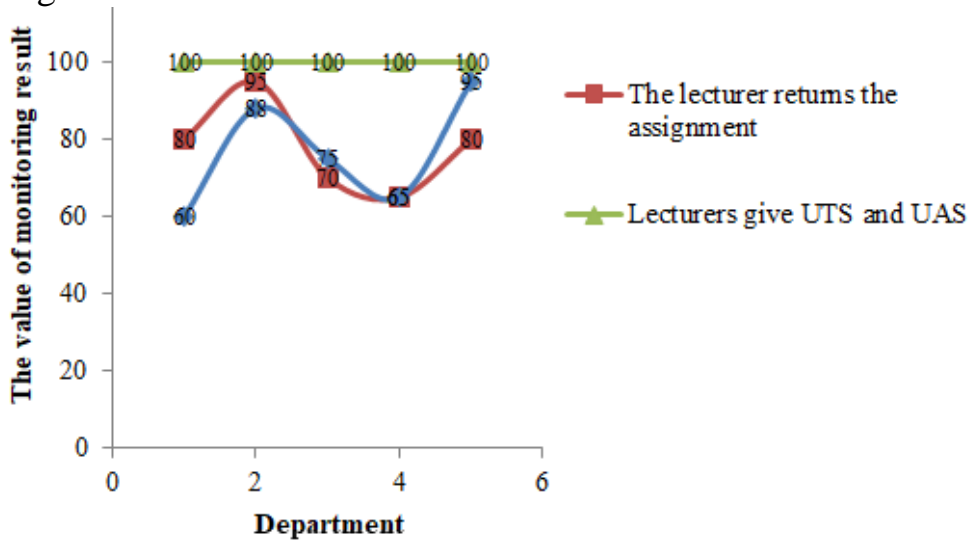

Figure 4. Results of the Learning Evaluation Stage

The data in Figure 4 shows that the average data value based on the six indicators for Civil Engineering; Electrical Engineering; Mechanical Engineering; and Technical Information is $80.0 \%$, respectively; $94.3 \%$; $81.7 \%$; 76.7 ; and $91.7 \%$.

Lecturers' perceptions about the quality of virtual learning can improve student learning outcomes indicating that $0 \%$ strongly agree that the quality of learning is in the very good category, $43 \%$ agree that the quality of learning is in good category, for $14 \%$ doubtful/say they quite agree that the quality learning in the good category, $14 \%$ stated that they disagreed that the quality of learning was in the good category, 30\% stated that they strongly disagreed that the quality of learning was in the good category. The results of lecturers' perceptions about the quality of virtual learning can improve learning outcomes are presented in Figure 5.

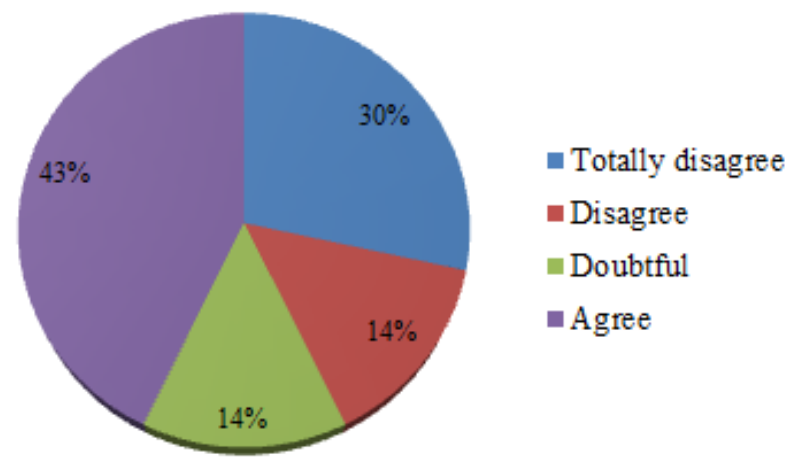

Figure 5.The results of lecturers' perceptions about the quality of learning can improve student learning outcomes in terms of the final grade of the course

Students' perceptions about the quality of virtual learning can improve student learning outcomes, indicating that $1 \%$ strongly agree that the quality of learning is in the very good category, $14 \%$ agree that the quality of learning is in the good category, $61 \%$ doubtful learning in the good category, $21 \%$ disagreed that the quality of learning was in the good category, $3 \%$ totally/stated strongly disagreed that the quality of learning was in the good category. Student perceptions about the quality of virtual learning can improve student learning outcomes are presented in Figure 6. 


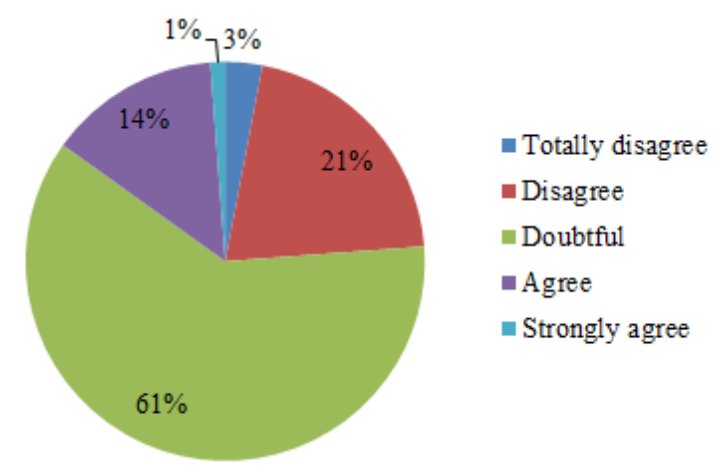

Figure 6. The results of student perceptions about the quality of learning can improve student learning outcomes

Some students have difficulties on the unstable signals when doing online learning. Student responses about obstacles in accepting online learning are presented in Figure 7.

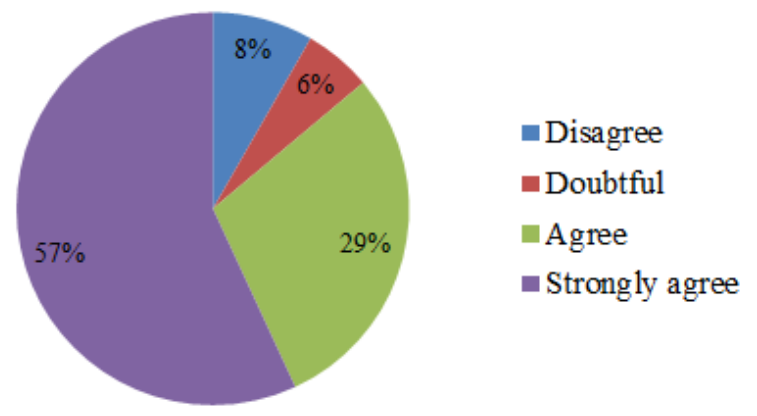

Figure 7. Student responses about obstacles in accepting online learning

The main problem that the lectures face was the difficulty in assessing student activeness and honesty in student evaluation activities. The lecturer response regarding this case in doing online learning is difficult to assess the activeness of students in an online learning is presented in Figure 8. The lecturer response regarding the obstacles in doing online learning is difficult to assess the honesty in doing the exam is presented in Figure 9.

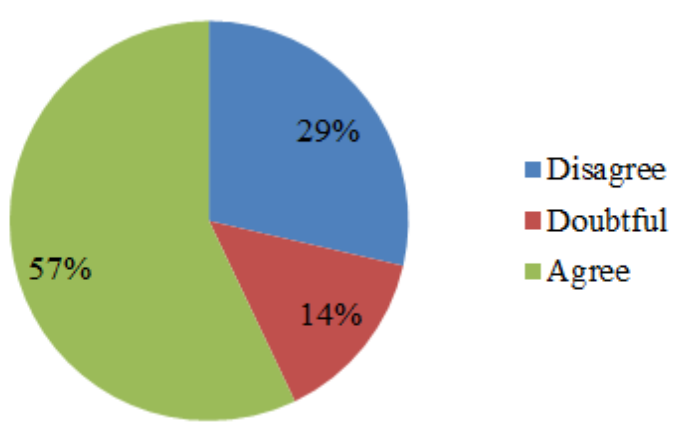

Figure 8 . The response of the lecturer regarding the obstacles in doing online learning is difficult to assess the activeness of students in participating in learning 


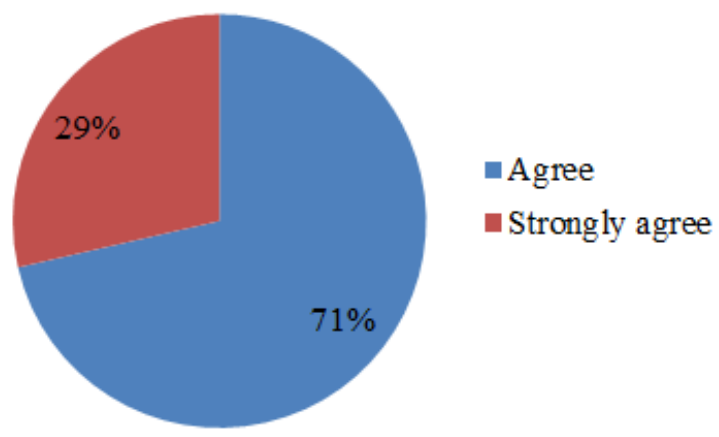

Figure 9. Lecturer responses about obstacles in doing online learning, it is difficult to judge honesty in doing exams

The first stage of learning preparation, implementation of learning, and evaluation of learning is in accordance with everything that has been previously planned. The results of lecturers' perceptions about the quality of learning can improve student learning outcomes in terms of student final grades in several courses, indicating that online learning is still felt to be needed for improvement and improvement in its use. There needs to be a combination with other applications, because virtual online learning emphasizes on the comprehending of the material. Collection of tasks requires other applications to meet expectations. The majority of students agree that the quality of virtual learning is sufficient to improve their learning outcomes. This has in common with the results of research on an increase in student learning performance when using virtual learning (Al-azawei \& Al-masoudy, 2020). Besides that, it is also in line with research on learning simulation models able to make better understanding of the material obtained by students (Pfahl \& Laitenberger, 2004), and learning modules presented in electronic media combined with discussion methods are able to improve concept understanding and problem solving (Wong et al., 2017). Network repair is also the important aspect to have better internet connection in order the class will run well during teaching and learning process.

\section{CONCLUSIONS}

The evaluation of the implementation of online virtual learning in students shows that (1) the implementation of online virtual learning during the Covid-19 pandemic can be carried out well, starting from the preparation, implementation, and evaluation of learning so that learning objectives can be achieved; and (2) implemented in accordance with the Lesson Plan Semester that was planned at the beginning of the lecture. The results of the implementation and suitability of the implementation of the Lesson Plan Semester are grouped into three stages, namely: (1) preparation for learning has an average score of more than $90 \%$ is ready; (2) the implementation of learning has an average value above $85 \%$ has been carried out well; and (3) the evaluation of lessons that have an average score of more than $75 \%$ has been done well. The quality of virtual learning in terms of the perceptions of lecturers and students shows that online learning has met the minimum criteria of good and sufficient. Students have some difficulties when they have unstable internet connection, they sometimes do not understand little information from their lectures. While for lectures, they are difficult in accessing students' activeness in doing the task or exam. This can be solved by adding certain time in doing the assignments. Monitoring can still be done by using other application such as Whatsapp Group to communicate with the students. Exam questions are packaged in such a way that puts forward variations in the form of questions so that students can work on the questions with the same goal with various models. 


\section{REFFERENCES}

Al-azawei, A., \& Al-masoudy, M. A. A. (2020). Predicting learners ' performance in virtual learning environment (VLE) based on demographic, behavioral and engagement antecedents. International Journal of Emerging Technologies in Learning, 15(9), 60-75. https://doi.org/https://doi.org/10.3991/ijet.v15i09.12691

Alomari, H. W., Ramasamy, V., Kiper, J. D., \& Potvin, G. (2020). A User Interface ( UI ) and User eXperience ( UX) evaluation framework for cyberlearning environments in computer science and software engineering education. Heliyon, 6(April), e03917. https://doi.org/10.1016/j.heliyon.2020.e03917

Hendriyana. (2011). Analisis Faktor-Faktor Yang Menentukan Kesuksesan E-Learning Di Sma N 1 Surakarta Tahun 2011 Analisis Faktor-Faktor Yang Menentukan Kesuksesan ELearning Di Sma N 1 Surakarta.

Jaya Kumar C. Koran. (n.d.). Dalam pengajaran dan pembelajaran di sekolah-sekolah malaysia.

Limatahu, I., \& Mubarok, H. (2020). CCDSR Learning Model : Innovation in Physics Learning. International Journal of Recent Educational Education, 1(1), 19-29. https://doi.org/https://doi.org/10.46245/ijorer.v1i1.13

Lincoln, Y. S. (n.d.). Effective Evaluation.

Novo-corti, I., Varela-candamio, L., \& Ramil-díaz, M. (2013). E-learning and face to face mixed methodology: Evaluating effectiveness of e-learning and perceived satisfaction for a microeconomic course using the Moodle platform. Computers in Human Behavior, 29(Juli 2012), 410-415. https://doi.org/10.1016/j.chb.2012.06.006

Pfahl, D., \& Laitenberger, O. (2004). Evaluating the learning effectiveness of using simulations in software project management education : Results from a twice replicated experiment. Information and Software Technology, 46(2), 127-147. https://doi.org/10.1016/S09505849(03)00115-0

Savec, V. F., \& Devetak, I. (2013). Evaluating the effectiveness of students' active learning in chemistry. Procedia - Social and Behavioral Sciences, 106, 1113-1121. https://doi.org/10.1016/j.sbspro.2013.12.125

Sax, G. (1989). Too of. In Principles of educational and psychological measurement and evaluation (3rd ed.) (pp. 278-279).

Tompong, B. N. K. J., \& Jailani. (2019). An evaluation of mathematics learning program at primary education using countenance stake evaluation model. Jurnal Penelitian Dan Evaluasi Pendidikan, 23(2), 156-169. https://doi.org/http://dx.doi.org/10.21831/pep.v23i2.16473

Wong, O. Y., Mrt, T., Gillan, C., Mrt, T., Harnett, N., Mrt, T., Li, W., \& Mrt, T. (2017). Evaluating the effectiveness of an electronic learning tool for volumetric imaging training-perceptions of radiation therapy professionals. Journal of Medical Imaging and Radiation Sciences, 48(4), 370-376. https://doi.org/10.1016/j.jmir.2017.08.005

Yigit, T., Koyun, A., Sinan, A., \& Arda, I. (2014). Evaluation of blended learning approach in computer engineering education. Procedia - Social and Behavioral Sciences, 141, 807812. https://doi.org/10.1016/j.sbspro.2014.05.140 